\title{
Literatura-Sociedad, en futuro. Los extremos de la república emergente en ensayos novelísticos de Lucio V. Mansilla.
}

Literature/Society, in future. The extremes of the emerging republic in novelistic essays of Lucio V. Mansilla.

Juan Pablo Luppi

Consejo Nacional de Investigaciones Científicas y Técnicas (ARGENTINA)

CE: pabloluppi@hotmail.com / ID ORCID: 0000-0001-9867-7017

DOI: $\underline{10.32870 / \text { sincronia.axxiv.n77.20a20 }}$

Esta obra está bajo una Licencia Creative Commons Atribución-NoComercial 4.0 Internacional $\mathrm{BY} \cdot \mathrm{NC}$

Recibido: 25/09/2019

Revisado: $10 / 10 / 2019$

Aprobado: 05/11/2019

\section{RESUMEN}

Mejor que prosista fragmentario sin novela (como lo clasificó Ricardo Rojas al instituir la historia literaria argentina en 1922) Lucio V. Mansilla (1831-1913) sería un escritor desplazado y fronterizo que propició una novela multiplicadora de su vida, cuyo valor estaba en el futuro. Entre la heterogénea producción desarrollada al margen del oficio castrense en la primera mitad de la década de 1860 como secretario en la Guardia de Rojas (Provincia de Buenos Aires), Mansilla redacta un Ensayo sobre la novela en la Democracia, publicado por entregas en el prestigioso diario porteño La Tribuna a fines de 1863, donde siete años después aparecerá Una excursión a los indios ranqueles. Desde un historicismo progresista diferido del romanticismo fundacional, el ensayo problematiza la imaginación de una novela plausible en la naciente democracia argentina, que encare desafíos morales y estéticos de la sociedad de individuos prácticos. Bajo resonancias retóricas de Sarmiento (escenas grandiosas, transiciones narrativas, sujeto como personaje, apelación persuasiva al lector, conocimiento por 
montaje) asoman tensiones culturales y personales que eclosionarán en Ranqueles, cuando Mansilla corrige desde la prensa el determinismo dicotómico del Facundo. Exponente de la transición conflictiva hacia la organización liberal de la nación en la periferia latinoamericana, la consideración de la novela en una democracia emergente enuncia problemáticas relativas a la representación y la autonomía, que permiten rastrear en el XIX la literatura del futuro.

Palabras clave: Crítica. Historia literaria. Democracia. Fronteras. Novela. Prensa.

\section{ABSTRACT}

Better than a fragmentary prose writer without a novel (as Ricardo Rojas classified him when instituted Argentine literary history in 1922) Lucio V. Mansilla (1831-1913) would be a displaced and border writer who fostered a novel multiplier of his life, whose value was in the future. Among the heterogeneous production developed on the margins of martial profession in the first half of the $1860 \mathrm{~s}$ as Secretary in the Guard of Rojas (Province of Buenos Aires), Mansilla writes an Essay on the novel in Democracy, published by deliveries in the prestigious Buenos Aires newspaper La Tribuna at the end of 1863, where seven years later will appear An excursion to the Ranqueles Indians. From a progressive historicism deferred from foundational romanticism, the essay questions the imagination of a plausible novel in the nascent Argentine democracy, which faces moral and aesthetic challenges on the society of practical individuals. Under Sarmiento's rhetorical resonances (grandiose scenes, narrative transitions, subject as a character, persuasive appeal to the reader, knowledge by montage) emerge cultural and personal tensions that will hatch in Ranqueles, when Mansilla corrects by the press the dichotomous determinism of Facundo. Exponent of the unsettled transition towards liberal organization of the nation in Latin American periphery, the consideration of novel in an emerging democracy states problems related to representation and autonomy, which allow us to trace the literature of the future in the 19th century.

Keywords: Criticism. Literary history. Democracy. Boundaries. Novel. Press. 


\section{Desde Rojas ${ }^{1}$}

\subsection{Límites historicistas de la república literaria}

Ocupado por el criterio monumental que organiza su Historia de la literatura argentina con los pedestales "épicos" de Facundo y Martín Fierro, Ricardo Rojas (1957, pp.427-434) ubicó a Mansilla como el primero de "Los prosistas fragmentarios" desplazados al final de la Historia (capítulo XVI de la quinta parte, "La prosa novelesca", del tomo Los modernos en 1922; a Mansilla le siguen Santiago Estrada, Miguel Cané, Eduardo Wilde, Bartolomé Mitre y Vedia, Fray Mocho, José M. Cantilo). Estos escritores compartirían una carencia: "desprovistos de ese espíritu de continuidad que en el pensamiento y en la obra crea la unidad orgánica del verdadero libro" a la altura de Amalia o La gran aldea, "la obra de aliento" que les falta es la novela. Desde la selectividad del nacionalismo culturalista sobre textos que pudieran ser útiles en la conformación de un canon sustentado en la historia patria, la valoración genérica limita la novela al "talento observador" iniciado por José Mármol y continuado por "novelistas modernos" como Lucio V. López, Eugenio Cambaceres, Julián Martel o Manuel Podestá. Más que ese vago talento observador (que también reconoce en los "fragmentarios") la pauta de valoración sería la fidelidad a normas genéricas establecidas por la retórica, la sujeción al estricto marco literario donde podían prestigiarse la oratoria y la didáctica antes que la anécdota y aún la novela, que representaba un déficit en el capital cultural necesario para la construcción de un sujeto nacional (Degiovanni, 2007, pp.185-189). Lo productivo del esquema filológico de Rojas sería la posibilidad (contrafáctica, desde su perspectiva) de entrever la cualidad novelística que moviliza la escritura de Mansilla, incluso en esa serie de autores de "breves relatos anecdóticos" que "estudiaron la psicología argentina [...] y describieron tipos y lugares con aguda observación, dejando entrever al novelista que cada uno de ellos hubiera podido ser en mejores condiciones de vocación intelectual y de cultura ambiente" (Rojas, 1957, p.427). Esta catalogación, que deniega el estatuto de "verdadero novelista" pero asigna lugar en "La prosa novelesca", puede enriquecer la significación crítica de

\footnotetext{
${ }^{1}$ Una versión inicial de este trabajo fue leída en el V Congreso Internacional Cuestiones Críticas, en la Facultad de Humanidades y Artes de la Universidad Nacional de Rosario, octubre de 2018.
} 
Mansilla un siglo después de Rojas. Indagando el estatuto de novela en relación con los riesgos del vértigo modernizador creciente en el último tercio del XIX, rastreamos la potencia contemporánea, inactual de la escritura de Mansilla en piezas no canónicas producidas a mediados de la década de 1860, fragmentos de prosa novelesca sin novela, ensayismo crítico sobre la novela como forma proteica ligada al devenir de la sociedad, cuya problematización del campo literario dispone interrogantes claves de la teoría y la crítica de fines del XX.

Al circunscribir la valoración de Mansilla a la vida anecdótica, la taxonomía de Rojas desestima el matiz relevante de tratarse de una vida escrita, legible como espacio novelesco de exploración de fronteras geográficas, culturales y subjetivas, trazado por la multiplicidad fragmentaria de un yo desplazado y oscilante. La estratificación de vida y escritura que Rojas aplica para negarle valor literario a Mansilla, ese "vasto caos autobiográfico" sin el cual sus fragmentos pierden "la mitad de su encanto" (p.434), acaso sea el rasgo que mayor pregnancia tiene en la novela futura, demorada en Argentina con respecto a México y Brasil que a mediados del XIX tienen ya sólida producción novelística. En efecto, "[e]l arte fue en Mansilla parte integrante de su vida”, como afirma Rojas, pero para nada "sólo puede salvarlo el considerar que practicó la vida como un arte" (p.434) sino que, desde el futuro ignorado por el historicismo, haber hecho escritura con esa práctica performativa lo vuelve más significativo en el cambio de siglo posterior al que vivió. Será cierto que (como a sus modos Macedonio Fernández, Borges, Osvaldo Lamborghini o Fogwill) "[c]reó un poema real: su propia biografía" y "un personaje novelesco: su propia personalidad" (p.434), pero se trata de creaciones escritas, eficaces para seducir y conmover al público de una prensa moderna, incipientemente masiva. La vida como poema y el autor como personaje serían rasgos devaluados en el emplazamiento institucional de la literatura argentina, pero pasibles de revaluación en los proyectos literarios que la complejizan al promediar el siglo XX.

Mansilla diseña un autor desfigurado en la letra que aporta una paradójica "unidad orgánica" hecha de dispersión, más vital que la del "verdadero libro" estipulado por Rojas para conformar la biblioteca nacional. Diseminada en formas y soportes disponibles en su presente (segunda mitad del XIX y primera década del XX), esa escritura de vida que ilumina la propia imaginación y excita la 
fantasía del lector contenía una proyección novelística cuyo valor estaba en el futuro: más visible en la alteridad polifónica de Una excursión a los indios ranqueles (1870) y el dialógico suspenso digresivo de las causeries reunidas en Entre-Nos (1889-90), la novela de Mansilla que no pudo leer Rojas se volverá contemporánea de Macedonio y el bucle metaficcional de la novela buena después de la mala, de Walsh y las notas dispersas para una novela geológica inacabada, o de Piglia y los diarios autobiográfico-críticos atribuidos a Renzi. Además, con impetuoso ademán caótico a la manera de Viñas (su más obstinado lector crítico), Mansilla trazó nudos de la hermenéutica sociohistórica que, entre seguimiento y discusión con Rojas, reordenaría la historia literaria argentina en el último tercio del XX. Interrogaremos una inicial sistematización de ese trazo, que materializa el entrevero de ficción, crítica y autobiografía, en una reflexión sobre la novela en democracia que Mansilla produjo en situación de frontera en 1863.

\subsection{Fronteras y tránsito}

Ya en las condiciones fronterizas de producción, como en las zonas más felices de la escritura de Mansilla, los extremos se aproximan. La tensión entre nomadismo y sedentarismo de la vida castrense moviliza la acción hacia adentro y afuera de la especialización militar, en un vértigo discursivo que sostiene su potencia en el yo que escribe y publica lo que vive, que hace de su vida una constelación de peripecias dignas de relato. Esta productividad anfibia tiene su antecedente en varios textos propiciados por la parsimonia burocrática en las fronteras internas de la nación en ciernes, formando parte del ejército de línea al que lo incorpora el favor del coronel Emilio Mitre en junio de 1861. Antes de las crónicas que envía con seudónimos a La Tribuna desde el escenario de la guerra contra Paraguay en 1865-66, la guarnición de Rojas (incipiente poblado en el límite noroeste de Buenos Aires) apaña una producción escrita tan abundante como heterogénea, en el incipiente contexto de reconfiguración vertiginosa de la escena cultural con centro en la república porteña de las letras, extendido hasta 1890 con la compleja superposición, que impide unificar rasgos por la pertenencia política, de diversas trayectorias entre hombres del interior y del exilio (E. Wilde, H. Varela, L. V. López, M. Cané), extranjeros que serían actores centrales en educación, prensa y gestión (A. Jacques, 
P. Groussac), jóvenes con inserción precoz en los nuevos ámbitos (M. García Mérou, A. Estrada) y porteños que no habían sufrido el destierro rosista (E. Holmberg, P. Goyena, J. M. Estrada, y aquí se inserta L. V. Mansilla, sobrino directo de Juan Manuel de Rosas) (Bruno, 2009, p.362).

Entre los borradores de Mansilla entre Rozas y París, proyecto que Viñas desarrolló entre 1999 y 2004, unas páginas impresas de procesador de texto con correcciones ológrafas se titulan "Rojas, aburrimiento y guarnición". Atento a las tensiones del escritor con la corporación militar, Viñas destaca este "momento Rojas" como inaugural vinculación de "Lucio Vé" con "el ordenancismo castrense", pautada por una labor de escritura "copiosa" sobre temas militares. Esta coyuntura sería parte del período de "tránsito desde la Confederación en declive hacia la próspera Buenos Aires" (Viñas, 1999-2004) con el padrinazgo de los Mitre, que Viñas titula 1861-1865. De Paraná a Buenos Aires. En medio de ese tránsito Mansilla produce el ensayo de reflexión histórica sobre la evolución social de la novela, junto con otras intervenciones críticas sobre cuestiones que la historia literaria del XX tenderá a circunscribir a las tres décadas siguientes a 1880, como la embrionaria profesionalización del escritor y la no progresiva autonomización literaria. Capitalizando su ya amplia experiencia en la prensa (en diarios oficiales de la Confederación separada de Buenos Aires hasta 1862), entre 1864 y 66 fundará y animará junto a José Manuel Estrada (de amplia experiencia y fuerte inserción periodística en Buenos Aires) el Círculo Literario, cuya esquela de invitación quiere llenar el vacío presente con el desarrollo futuro de la literatura nacional:

Las bellas letras argentinas [que están] adquiriendo un desarrollo consolador para el futuro, y constituyendo poco a poco una profesión o modo de vivir, sienten sin embargo, desde hace mucho tiempo un gran vacío por la falta de un punto de reunión" para el intercambio presencial y la "mancomunidad", necesarios "si en verdad se quiere que [...] prospere y se engrandezca nuestra literatura" (citado en Bruno, 2009, pp.347-348).

La textualidad de Mansilla está atravesada por el desplazamiento multidireccional de esa performatividad literaria para generar con palabras su espacio autónomo (sus condiciones discursivas específicas, no por eso desligado de lo social) y un potencial "modo de vivir" que tensa lo social con 
el predominio individual. Al margen de su tarea presunta como secretario que lleva la correspondencia del enclave fronterizo, en su momento Rojas Mansilla genera obras de técnica y pedagogía militar (en 1860 ya había cumplido como letrado con la demanda castrense, cuando la Imprenta de la Paz publicó su Plan de defensa de las fronteras de Buenos Aires), traducciones (Vigny, Babrac), relatos del viaje a Oriente y Europa realizado en 1850-51 (Recuerdos de Egipto en Revista de Buenos Aires, 1864), dos obras de teatro que, con tramas y diálogos novelescos, detectan contradicciones democráticas y alertan sobre peligros del vértigo capitalista como el esclavismo y el lugar social de la mujer (Atar Gull o una venganza africana, retomada de 1855, y Una tía, ambas estrenadas exitosamente en Buenos Aires en 1864). Entre la multiplicidad productiva amparada en el tedio de la Guardia de Rojas aparece el ensayo historicista, dedicado a la novela bajo sistemas democráticos como el que por entonces comenzaba tensamente a ejecutarse en Argentina, donde acaso no fuera urgente el problema del esclavismo (Atar Gull ambienta en Brasil una trama novelesca plagiada de Eugene Sue) pero sí el de la inserción doméstica y pública de la mujer (Una tía presentiza en Buenos Aires en "186..." una trama de coquetismo, familia y dinero, al modo de la novela de Machali que Mansilla reseñara meses antes). ${ }^{2}$

No por nada la sobrina coqueta de la tía táctica, en dicha obra, tiene el mismo nombre que titula tópicamente Emilia o los efectos del coquetismo, la novela de Ramón Machali publicada con seudónimo R. el Mujiense por la Imprenta de la Bolsa en 1862. Tal disparador tuvo efecto teatral y antes ensayístico: a fines de 1863 Mansilla envía a La Tribuna, el influyente periódico de sus amigos Varela, las cuatro entregas del Ensayo sobre la novela en la Democracia o Juicio crítico sobre la Emilia de R. el Mujiense. Producida desde un borde geográfico, militar, político de la nación en los inicios de la organización liberal -y literaria: en 1873 la Academia Argentina impulsa "la organización del corpus de la literatura nacional" (Bruno, 2009, p.350) que medio siglo después consumará Rojas-, publicada en el centro del espacio impreso nacional renovado después de Caseros y hegemónico

\footnotetext{
2 También en 1863 Mansilla publica en la recién fundada Revista de Buenos Aires -emblema de la unificación nacional que fusiona la revista dirigida por Vicente Quesada en Paraná con la porteña dirigida por Miguel Navarro Viola (Bruno, 2009, p.354) - dos notas dedicadas a "La literatura argentina en Alemania", a propósito de la traducción de El médico de San Luis, novela de su hermana Eduarda Mansilla.
} 
después de Pavón (un diario porteño fundado en 1853, con apoyo material del gobierno, por los hijos del mártir del rosismo Florencio Varela), la consideración crítica de la literatura en una democracia periférica esboza modalidades enunciativas que darán carácter singular al estilo de Mansilla, y en la formalización de un historicismo que reúne literatura y sociedad abre diálogos inactuales con el inmediato pasado romántico y con los debates recurrentes sobre la institucionalización de la literatura nacional.

\section{Impresión y postergación}

Cuesta visualmente encontrar el Ensayo de Mansilla entre las ocho columnas abigarradas de la primera de las cuatro páginas del diario La Tribuna $(54-81 \mathrm{~cm}$.), decano periódico porteño que por entonces se acercaba a su número tres mil. De las cuatro entregas enviadas desde Rojas, solo la segunda y la cuarta tienen más diáfana ubicación en el ángulo inicial, arriba a la izquierda. ${ }^{3}$ El tercio inferior de la primera página está ocupado por el folletín, que en esos días publicaba, desde hacía más de un mes, Los enemigos del alma del exitoso Manuel Fernández y González, novelón sentimental que bien hubiera servido a Mansilla para las mismas reflexiones que atribuye al de Machali. La apertura y el cierre de la serie dan la ubicación temporal ("Noviembre de 1863") precedida por la espacial ("Rojas"). Repitiendo cada vez la volanta que destaca en mayúscula aquello que, pese a la tipografía de lo fáctico, aún no existe y se busca en el futuro - "Literatura nacional" , las cuatro entregas se despachan en menos de una semana, alterando el ritmo diferido y la duración extensible del folletín, cuyo espacio en el mismo diario ocuparán durante dieciséis semanas las sesenta y seis entregas de Ranqueles. Menos en la forma genérica o el soporte gráfico, lo folletinesco asoma en la posición enunciativa de un yo dinámico para crear complicidad con los lectores. Sobrepasando la fijación del impreso y posando de ensayista argumentativo, Mansilla superpone una

\footnotetext{
${ }^{3}$ La primera entrega ocupa tres cuartos de la segunda columna hasta otro tanto en la sexta; más breve, como si se reservara el máximo para la promesa de concluir en la siguiente, la tercera entrega abarca desde el segundo cuarto de la sexta columna hasta casi el final de la octava. Ambas fueron en cada caso la segunda nota de primera página. La primera entrega apareció en el número 2967 del diario, fechado 23 y 24 de noviembre; la segunda, el 25; la tercera, el 27; y el 28 la última. Consulté y fotografié el diario en la Hemeroteca de la Biblioteca Nacional de Argentina: La Tribuna. Buenos Aires: Imprenta Progreso, 1853-[1884?]. Ver Anexo.
} 
distribución tipográfica en cinco partes encabezadas por números romanos, cuyo ordenamiento retórico exhibe su envés con algunos comentarios que apelan al autotematismo digresivo que marcará la diégesis flotante de Ranqueles y las causeries: "Pero me alejo sin querer de mi objetivo, y es menester que recobre mi hilo conductor", "Así, pues, continúo pidiendo perdón al lector por haberle engolfado en tan altas y serias reflexiones, y por la manera informe y confusa como todas ellas de mi pluma han brotado", "Mas observo al llegar aquí que mi plan ha corrido demasiado" (Mansilla, 2013, pp.126, 137, 149). ${ }^{4}$ A diferencia de la Emilia de Machali y aún de su reversión mansilleana en Una tía, el ensayo libera la digresión del registro valorativo, frecuente en las variantes usuales de la novela de la época (social, sentimental, política, histórica) (cf. Molina, 2011, p.321). Folletinesco más allá del soporte (pero acorde con su disposición y línea editorial), el nomadismo digresivo de la prosa de Mansilla multiplica las variables de valoración entre la moral y la literatura, traspasa fronteras entre interior/exterior e imprime otra movilidad a los binarismos románticos residuales en el historicismo de Rojas. La novela puesta como foco ensayístico da espacio tonal a un narrador de novela de aventuras (del pensamiento) que existiría en la literatura argentina un siglo después, más cercano a Macedonio o Aira que a Machali.

La materialidad de la prensa brinda a Mansilla el espacio donde jugar con la transmutación de lo interior y lo exterior, en el propio texto y en el pensamiento del texto sobre sí y su lectura. Como hará en muchas dedicatorias de causeries y en la apertura dialógica con Santiago Arcos en Ranqueles (sobre haberle "ganado de mano" en comer tortilla de huevos de avestruz), antes de la parte I del Ensayo inserta la "Dedicatoria", a Rufino Varela (fundador del diario familiar con sus hermanos Héctor y Mariano, que a diferencia de Mansilla logrará un ministerio en el gobierno de Juárez Celman) recordando "la disputa con aires de calorosa [sic] discusión, que a propósito de una frase mía se suscitó en la redacción de La Tribuna la última vez que estuve en esa" (Mansilla, 2013, p.118). Rufino se ha hecho dedicatario porque "al borronear las páginas adjuntas esa misma frase ha brotado de mi pluma, recordándome el nombre de usted" (p.118), sin que nos devele la frase en cuestión (omisión

\footnotetext{
${ }^{4}$ Actualizo ortografía en citas de esta edición.
} 
excesivamente compensada con el ensayo que vamos a leer). El resto de la dedicatoria se desdobla hacia el otro dedicatario que Mansilla hace cómplice de su escritura, el anónimo lector de prensa, cuya impaciencia (con que se solazarán las causeries) ampara la decisión de publicar el Ensayo en un soporte, el diario, "cuya vida es tan efímera", consciente de que "las páginas donde haya de ser estampado, deban servir para envolver alcaravea, un momento después de lanzadas a la circulación" (p.119). ${ }^{5}$ Para afianzar la efectividad escrituraria, el ensayista se afirma en el borde peligroso entre el libro y el diario, lo permanente ("monumento del pensamiento humano", autoironiza sobre su ensayo, hasta hoy externo al libro) y lo efímero, bromeando sobre su propia impaciencia de lector: "Yo de mí sé decir que cuando al pie de un escrito, leo el terrible continuará, casi siempre lo hago a un lado, sobre todo si es una revista mensual lo que leo". La ansiedad adjudicada al lector justifica la elección del medio: como "las intermitencias serán mucho más breves, de 24 horas apenas, no me asusta el peligro de poner a prueba la paciencia del lector". Triunfal, la penúltima entrega del Ensayo reemplaza el terrible "Continuará" de las dos entregas previas por un irresistible "Concluirá" (p.143). El autor domina la temporalidad de una reflexión sostenida menos en la ilación argumentativa que en el montaje arbitrario y seductor; con la promesa o ilusión novelesca de llegar a un Fin redituable, incluye al lector en la trama textual, al soporte en el texto, a la literatura en la sociedad.

La prosa de Mansilla sostiene la conjugación en futuro dilatando la promesa; el ensayo es doblemente novelístico, por su asunto establecido en el título, y por su forma difusamente argumentativa y lúdicamente subjetiva. La postulación de un ordenamiento retórico es tan aparente como su presunta conclusión: las partes del discurso funcionan menos como sustento de una lógica expositiva que como embragues narrativos, apelaciones irónicas sobre el propio avance de un

\footnotetext{
${ }^{5}$ La frase jocosa sobre la materialidad efímera y proteica del soporte (el diario convertido en envoltorio de verdura) es expandida por Cortázar en el microrrelato "El diario a diario", que concluye con una anciana que encuentra en un banco de plaza el diario leído que ha quedado como "montón de hojas impresas", y luego de leerlo y reconvertirlo momentáneamente en diario, "lo usa para empaquetar medio kilo de acelgas, que es para lo que sirven los diarios después de estas excitantes metamorfosis" (1994, p.71). Los desplazamientos materiales pueden ser significativos para la trama, como la peripecia novelesca encastra en el espacio periódico del folletín. Como analiza Schvartzman en el Santos Vega o los mellizos de La Flor (1872) de Hilario Ascasubi: "Folletinescamente", lo que se lee en un pedazo de gaceta que envuelve la yerba es recuperado para la peripecia. Los restos de la cultura impresa y sus implicaciones sucesivas serían "la estación de un amplio y aleatorio circuito de lectura de la letra impresa periódica" (2013, p.190).
} 
discurso sin orden, comandado por un escritor/lector que sin embargo, en la teoría de lectura que esboza, se atiene a la ideología procesual. Las cuatro entregas, en particular las dos primeras pero también la parte $V$ en la entrega final, están atravesadas por el paradigma del proceso de la civilización y la creencia en la ley soberana del progreso, "lento, gradual; pero sin fin" (p.122). Rivalizando con la autosuficiencia sarmientina en su propio terreno, (auto)cita de un discurso "que ha poco pronuncié al inaugurarse una escuela pública en Rojas" estadísticas sobre crimen y educación en Europa, que probarían que los males sociales no son inherentes a la civilización moderna sino que, al contrario, "la ilustración [...] aleja de los fosos de corrupción” (p.144). Este progresismo ilustrado será matizado siete años después, cuando Mansilla desacata la obediencia debida para, en vez de quedarse escribiendo en la frontera, cruzarla hacia las tolderías y escribir lo que allí vio, mostrando la excepción inscripta en la ley del progreso, relajando el tono con acentos menos esquemáticos: Una excursión a los indios ranqueles es el folletín de la agonística democrática, inimaginable en 1863, contemporáneo de novelas que interrogan la novela a fines del XX como las de Saer o Aira. Durante medio siglo, en la vida y la escritura, el impulso de Mansilla es el movimiento, lo progresivo; pero distorsiona esa doxa de su tiempo agregándole el nomadismo de la propia vida reduplicada en lo escrito, la movilidad de oficios e ideas, la inaudita aproximación de los extremos: formula a destiempo las paradojas irresueltas del proceso civilizatorio. El ensayo del 63 inscribe este sesgo inconformista en el desfase de la novela argentina en relación con el estado de la sociedad; impulsa en el terreno de la crítica una respuesta a demandas que le vienen del futuro. ${ }^{6}$

Astuto, el ensayista recorta el panorama histórico para validar su premisa. Al final de la primera entrega afirma que "Hay aserciones que es fácil autorizarlas con la voz de la historia” (p.128), como la que acaba de estampar: la literatura es más épica y dramática bajo el despotismo. Usando el espacio tipográfico del modo salteado que lucirán Ranqueles y las causeries (que pasando del diario al libro evitan la metamorfosis entrópica en paquete de verdulería o libraco de hemeroteca), la citada

\footnotetext{
${ }^{6}$ La recepción actualiza y transforma los elementos textuales: "las obras se escribieron en el pasado pero siempre se leen en el presente, creando significaciones actuales: la obra literaria pasada contesta en el presente, es decir que contesta a una solicitación que, para ella, viene del futuro" (Premat, 2018, s/p).
} 
afirmación forma una oración-párrafo, seguida por otra que cierra la primera entrega: "Voy entonces a invocar su testimonio" (p. 128) (el de la historia). Y la entrega siguiente arranca con el movimiento espectacular que en una frase nos lleva a los orígenes de la historia occidental - "Si me remonto a nueve siglos antes de Cristo [...], a la época de Homero" (p. 128) - para ir abarcándola en párrafos breves, uno para Demóstenes, otro para Virgilio, luego Cicerón, Dante, Tasso, etc., hasta llegar en una veintena de párrafos a Fenimore Cooper, que encontró asunto para la novela norteamericana en el océano y los mohicanos $-\mathrm{y}$ fascinó a Sarmiento, como se disfruta en el segundo capítulo del Facundo- (pp.128-134). El vertiginoso "testimonio histórico" tornaría evidente la premisa de que, en $186 \ldots$, en los comienzos de la organización republicana de la nación, el tiempo de la novela es el futuro: si la democracia es una "forma social fortificada por el vínculo federativo", y "[e]n la atmósfera democrática, el individuo se hace más práctico que teórico, más aventurero que pensador" (p.123), sería inevitable la demora en el desarrollo de las ciencias y las artes. Con la pose lógica de la formulación condicional, la primera entrega postula: "si tal es la obra que la democracia está llamada a realizar, es solo en épocas distantes de nosotros, remotas quizá, que las ciencias abstractas, las bellas artes y las letras, adquirirán en ella grande y pujante desarrollo" (p.123). La poética romántica, el "arte considerado del punto de vista estético" deberá decantar en una provechosa pasión por "lo grande y gigantesco", más atenta al territorio empírico que a los paisajes líricos (el Desierto de $L a$ cautiva de Echeverría como espacio nacional en 1837), enfocada ya no en arquetipos románticos sino en el individuo democrático, "más positivo que idealista" (p.123). Absuelto de planteos trascendentales sobre el ser argentino, a Mansilla no le preocupa el individualismo inevitable de una democracia capitalista. La atención crítica a la sociedad contemporánea torna arcaico el enfoque patriótico sostenido por V. F. López menos de diez años antes en la rudimentaria novela nacional, cuando La novia del hereje o La Inquisición de Lima demandaba el conocimiento del pasado para evitar un futuro incierto, abandonado "a las convulsiones y los delirios del individualismo" (cf. Molina, 2011, p.252). 
Bajo la teorización estética emergen tensiones políticas con la propia clase, en relación generacional desfasada. ${ }^{7}$ El énfasis puesto en el vínculo federativo denuncia el centralismo como factor que demora la realización anhelada, acaso en alusión al gobierno nacional asumido un año atrás por Bartolomé Mitre, estampando los vaivenes de ese tránsito ideológico destacado por Viñas y analizado como fusión de empresas periodísticas por Bruno, desde la Confederación de Paraná que lo había amparado a fines de la década del 50 hacia la prosperidad orientada por Buenos Aires luego de Pavón:

Háblase mucho de democracia y libertad, y, sin embargo, icuán lejos estamos de ser genuinos demócratas aquí donde la república, si bien no tiene un rey, más se parece a una monarquía constitucional, consolidada por la unidad económica y administrativa, que a una nación constituida por el vínculo federativo [...]! (Mansilla, 2013, p.126).

El primer párrafo del ensayo había explicitado el programa de "la democracia de nuestros días", sostenido en "la instrucción primaria entre todas las clases de la sociedad", la libertad de pensamiento, acción y cultos, "la perfecta ecuación del impuesto", "la igualdad ante la ley", "el libre cambio", "la descentralización administrativa y el sufragio universal", "pugnando por poner en todas partes la autoridad al servicio de la libertad" y "hacer triunfar la única política honrada -la política del derecho" (pp.119-120). Bajo la utopía continuadora de Alberdi y Sarmiento reverberan tensiones internas al grupo dirigente, con la demanda de que una democracia debe calibrar el liberalismo económico con la descentralización y la participación cívica, vislumbrando el nudo de la conflictividad gubernamental hasta $1916 .{ }^{8}$

\footnotetext{
${ }^{7}$ Demasiado joven para la afamada generación de desterrados antirrosistas (amén del desplazamiento inocultable por ser sobrino directo de Rosas) y algo mayor para los nuevos dirigentes del 80, Mansilla ha sido ubicado en una nebulosa segunda generación romántica, a la vez que su estilo se considera precursor del tono ligero que, desde Rojas, tipifica la generación del 80 (cf. Myers, 1998). En términos generacionales resulta tan movedizo e inclasificable como en los términos filológicos y genéricos de Rojas.

${ }^{8}$ En 1916 la democracia adquiere legitimación política en Argentina, cuando la Unión Cívica Radical lleva a la presidencia a Yrigoyen. En cambio, la democracia de la que habla Mansilla es menos un hecho legal que un hecho social, con la marca alarmada de Tocqueville (cuya mirada se ciñe a Estados Unidos) sobre la ruptura de la cadena aristocrática y la dispersión de los eslabones encerrados en la soledad, prevención sobre la igualdad como mediocridad que influirá en Renan y Taine hacia el fin de siglo. Al observar esta incidencia en Miguel Cané (h), Terán (2000, p.41) deslinda el matiz que cabe para
} 
La democracia aparece como factor dilatorio del desarrollo novelístico, y suscita una prevención pragmática que matiza el fervor romántico de la generación fundacional. El arte de la democracia incipiente deberá superar las resonancias del desierto inconmensurable de La cautiva de Echeverría y el mal de la extensión que aqueja a la Argentina impresa en el Facundo, para no obstante seguir persiguiendo una utilidad comunitaria, alguna "conclusión" promisoria, tensada con "continuaciones" abiertas. Conclusivo y programático era el tono romántico para estipular la necesaria congruencia entre arte y sociedad. En 1841, con ocasión del Certamen poético de Montevideo, al considerar que "los cambios sociales arrastran transformaciones culturales", Alberdi establecía una adecuación exacta entre literatura e historia bajo formas democráticas (Rodríguez Pérsico, 2017, p.30), donde amparaba los deslices de las literaturas democráticas: "El desorden, el abandono e incorrección del estilo [...] es también una calidad inherente y normal de las literaturas democráticas" (Alberdi, s/f., p.130). Más decidido en la estipulación de caracteres fuertes para la literatura nacional, en similar situación de destierro (aunque lejos de los poetas de Montevideo, envuelto en el diarismo de Chile), Sarmiento toma el modelo novelístico de la democracia norteamericana (Cooper) y, en el segundo capítulo del Facundo, proyecta la literatura nacional por el contacto de la "pluma del romancista" con las "grandiosas escenas naturales" y la "lucha entre la civilización europea y la barbarie indígena, entre la inteligencia y la materia" (Sarmiento, 1961, p.41).

Apenas iniciado en su propia aventura de conquista, que en Ranqueles tornará reversible la relación entre civilización y barbarie, Mansilla lanza la imaginación de una novela argentina de la democracia capitalista, más práctica y positiva que teórica e idealista, que encare los problemas de la nueva sociedad de individuos aventureros. Como exhibirán las variadas escenas dialógicas en Ranqueles y las causeries, esa sociedad se textualiza en términos novelescos de personaje, con figuras tan singulares que, como el autor, evaden la acusación de individualismo, en una senda estético-

Mansilla en 1863: "el término 'democracia' no significaba solo ni prioritariamente un nuevo tipo de legitimidad política fundado en la soberanía popular, sino lo opuesto a un buen orden jerárquico aristocrático", cuya peligrosidad se adjudica (en 1863 y hasta bien entrado el siglo XX) al "cruce del fenómeno de las masas con la inmigración". 
política marcada por Sarmiento en Facundo y Viajes. ${ }^{9}$ Su textualidad posterior -el decisivo viaje a los ranqueles le aporta sus propios mohicanos sin recurrir a Cooper- supera las dificultades que detectaba en 1863 para realizar novela bajo la nueva democracia. Dinámicas entre crítica, autobiografía y ficción, las resoluciones narrativas de Mansilla reformulan la programática estéticopolítica estipulada por Echeverría, Alberdi, Sarmiento, López. La tipografía hinchada de "Literatura argentina" en la primera página de un acreditado diario nacional corporiza lo que todavía no existe, al margen de lo proclamado como existente en la apasionada fundación romántica.

\section{Nación y pasión}

Los opuestos de interior/exterior se aproximan en diversos niveles textuales y contextuales. Preludiando debates sobre inmigración durante el primer tercio del XX y paranoias de la novela naturalista con inmigrantes patologizados en el 80 - ¿inocentes o culpables? (1884) de A. Argerich, En la sangre (1887) de E. Cambaceres, Irresponsable (1889) de M. T. Podestá- Mansilla en el 63 protesta que "el matiz de las costumbres nacionales desaparece gradualmente, confundiéndose entre los diferentes tintes exóticos" (Mansilla, 2013, p.135). La prevención contra la igualdad como homogeneidad apela a la figura del gaucho, anticipando la canonización del Centenario, más en su veta nostálgica que en la nacionalista paranoica de Rojas y sobre todo de Lugones: "Hoy el gaucho tipo exclusivamente nacional ha desaparecido del todo [...]. Es que las costumbres democráticas van nivelando, igualando y haciendo homogéneo y fraternal, lo que antes no lo era" (p.135). Siete años después afinará una tipología del gaucho que corrige la del Facundo, y diseñará estrategias narrativas para incrustar en el decurso novelesco de Ranqueles la vida fronteriza de gauchos contada por ellos mismos, que así devienen personajes. Más en sintonía con los miedos del 900 que con la temeridad de 1870, en el 63 Mansilla lamenta la mezcla inmigratoria que quitaría eficacia social a la novela

\footnotetext{
${ }^{9}$ Como en Facundo, en la carta sobre "Estados Unidos" de Viajes (1849) el pensamiento social se materializa en términos de personaje; en la admirada democracia republicana Sarmiento no encuentra al individuo moderno ni, por lo tanto, repara en los riesgos del individualismo exacerbado que preocupaban a Tocqueville (Roldán, 2005, pp.45-46). Mansilla profundiza esa línea que, sobrepasando prevenciones satíricas sobre "Nuestro pecado de los folletines" (artículo de Sarmiento en El Progreso en agosto de 1845), encuentra rendimiento narrativo en la concepción folletinesca del sujeto como personaje -incluso aplicada sobre sí mismo, como no pudo valorar Rojas-.
} 
argentina. La moda "por decirlo así" derrota a "las cosas de la tierra cayendo día a día en desprestigio mayor", y la novela, "esta forma popular de la literatura moderna", debe recurrir a "lo prestado" y "lo fantástico", rayando en lo inverosímil y perdiendo utilidad instructiva (p.136).

Esbozando tensiones sociocríticas y debates teóricos que, con diversos énfasis ideológicos, tendrán auge al promediar el siglo XX, Mansilla encara tentativamente (ensayísticamente) el problema de cómo relacionar el arte con la historia social. La conclusión de la primera entrega coincide con el cierre de la parte I, y antes de pasar a invocar el testimonio de la historia, asegura que es fácil que este autorice la aserción concluyente: la literatura encuentra mejores condiciones para la épica y el drama bajo el despotismo, porque en democracia "no habiendo en los episodios de vida real suficiente hechizo, ni para el romancista, ni el poeta, su fantasía será excitada con dificultad" (p.128). El ensayista aboga por aquello que será central en su estilo dilatorio, dialógico y autorreferencial: una manera de narrar episodios de "vida americana" y pensamiento sin perder animación, sosteniendo la atención difusa de lectores de prensa. Con los procedimientos digresivos, la exhibición del autor y la performance discursiva que tensa la impaciencia del lector, la escritura marginal en la frontera de Rojas materializa conflictos que sobrepasan el historicismo de las fronteras taxonómicas de Rojas (Ricardo) y, con potencia anacrónica, resuenan en los debates de la teoría literaria que en el último tercio del XX complejiza la determinación mutua entre el texto y lo social. Los bordes entre las series estética, cultural, histórica suscitan complejas aproximaciones analíticas, desde que la "estabilidad de las relaciones literatura-sociedad es una ilusión histórica y teóricamente indemostrable" (Altamirano-Sarlo, 1993, p.59). Al planificar nuevas perspectivas teóricas en la transición democrática de la década de 1980, con la premisa de que "[e]l texto literario se constituye en la heterogeneidad" (p.15), Altamirano y Sarlo reseñan de Starobinsky la comprobación de que el límite entre la obra y su afuera cambia históricamente; en debate abierto con la sociocrítica (Williams, Althusser, Kristeva) la cuestión central sería el modo de visualizar el afuera del texto sin perder atención a su interior, reconociendo que "[l]a atención del interior nos lleva al afuera" (p.59).

En su ensayo sobre Literatura/Sociedad desfasado a 1863, Mansilla iría del exterior (la evolución histórica de la novela y su estado presente bajo las democracias modernas) al interior (los 
procedimientos textuales de Machali, el estilo de una novela reciente y corriente como excusa del desarrollo previo). Como si en la tercera entrega, luego del panorama historicista que copó las dos anteriores, hubiera recordado el título y "el anhelo que he tenido de abordar cuanto antes el tópico principal" (Mansilla, 2013, pp.137-138), dispone una parte III, la más breve, integrada por dos párrafos que sirven de bisagra entre aquel desarrollo y el abordaje de Emilia o los efectos del coquetismo, "novela de costumbres" que pronto clasifica como "una de tantas novelas sentimentales" (pp.137-138) cuyo afán instructivo se aboca previsiblemente al control de la mujer. ${ }^{10}$ El primer párrafo plantea el problema de la pertinencia: "si vale la pena de que el crítico se ocupe detenidamente en aquellas producciones cuya tela sea exclusivamente la vida americana" (pp.137138); el segundo párrafo considera innecesario responder a dicho problema: “No disertaré sobre este punto porque decir que sí vale la pena es un corolario que se desprende de lo dicho hasta aquí" (pp.137-138). Con fervor subjetivo a lo Sarmiento (sin el rigor dogmático de Echeverría o Alberdi) las ideas se sustentan, novelescamente, en la fuerza retórica. Allí inserta el citado pedido de perdón al lector por "la manera informe y confusa" en que las reflexiones han brotado de su pluma (Mansilla, 2013, p.137). ${ }^{11}$ Sigue en la misma tercera entrega la parte IV, decidida a encarar el objeto propuesto en el título y pospuesto en las tres partes previas. Y justamente el diálogo con el lector es el eje definido para el abordaje textual: "R. el Mujiense [...] ha elegido el género más difícil, es decir, el género narrativo, porque siendo este una especie de diálogo con el lector, es necesario que la animación se sostenga hasta el fin" (p.138). La exigencia de entablar una acción que mantenga excitado al lector estaría depreciada por la demanda moral: Mansilla critica el modo específico de insertar en la forma narrativa la instrucción que debía prestigiar al género. Hinchado de máximas morales que provocan contradicciones, el libro elegido sería contraejemplo de la novela argentina posible: "en la novela, la moral debe consistir, no tanto en los pensamientos, cuanto en las diversas

\footnotetext{
${ }^{10}$ Emplazada en lo sentimental equivalido a lo femenino, la novela latinoamericana se afianza como medio instructivo de conductas vinculadas al ocio y la lectura. Como sintetiza Zanetti $(2002$, p.125) la novela "ayudaba a singularizar las subjetividades de los personajes, distinguidas por rasgos valorados o rechazados (muchas veces mediante tópicas suficientemente afianzadas en los relatos que llegaban sobre todo de Europa), a la vez que diseñaban conductas sobre el uso del libro y el ocio en los diferentes sectores integrantes de la nación".

${ }^{11}$ Itálicas en original.
} 
situaciones que se pintan" (p.138). En 1863 ya cabe la atinada crítica a novelas de tesis que serán señeras en el mercado literario justo después de la intervención académica de Rojas ( $E$. Larreta, R. Güiraldes, M. Gálvez, E. Mallea).

Cara al romanticismo, la analogía plástica orienta el análisis de los personajes como tipos, cuya excelencia apunta al realismo porque depende del manejo diestro del pincel para lograr que "los colores de su paleta [sean] vivos como los de la naturaleza" (pp.140, 142). La naturalidad del estilo que distancia el pintoresquismo será un afán visible en el modo de trasuntar las voces de indios y gauchos en Ranqueles. El ritmo folletinesco y la potencia digresiva asoman en el 63 como rasgos decisivos de la singularidad poética y el descentramiento político de Mansilla. En los últimos párrafos del ensayo la autosuficiencia persuasiva incluye a los lectores, con la fuerza probatoria de una retórica publicista digna de Sarmiento: “Ahora bien, ¿̇pondréis en duda después de haberme leído, que el apogeo literario de la novela en la República Argentina está lejano aún?” (p.150). Bajo prevenciones sobre la evolución democrática (que tendrán resolución legislativa en 1912), Mansilla remarca aquello que será un procedimiento novelesco en relatos de viaje por la prensa periódica en los 60 y 70 (Recuerdos de Egipto, Ranqueles, Minas de Amambay) y en las causeries de 1890: el diálogo eficaz entre el texto y su lector anónimo pero íntimo, orientado por la dosificación de la impaciencia mediante el manejo de transiciones, como sugiere corregir en futuras obras del novelista reseñado: “ese anhelo impaciente de hacerle ver el fin al lector. El lector tendrá paciencia, y gozará doblemente viendo producirse los cambios con más naturalidad" (p.139).

Como la de Machali con su título típico y su limitado objetivo sintetizado por Mansilla (“inspirar horror al coquetismo") (p.138), la novela sería el género ligado al ocio doméstico asignado a la mujer, frecuentemente puesta como personaje ambiguo envuelto en historias de amor, mientras que las dimensiones sociales e históricas daban su prestigio a los romances fundacionales, como en la pluma del romancista que Sarmiento celebraba en Cooper. ${ }^{12} \mathrm{Y}$ aunque el público del folletín

\footnotetext{
${ }^{12}$ En 1957 el programa de Literatura Argentina II de la Universidad de Buenos Aires, a cargo de Antonio Pagés Larraya y Guillermo Ara, incluye Emilia o los efectos del coquetismo como sexta novela de la unidad VIII: "La novela sentimental. El folletín. La influencia de Madame de Stael y de George Sand" (Exlibris número 1, FFyL, UBA, 2012).
} 
periódico se nutrió de mujeres emplazadas en el mundillo de las pasiones, las razones (y sanciones: bovarismo, adulterio, chisme, coquetismo) eran esgrimidas por varones que ocupaban el lugar de autor, editor (a menudo director de periódico) y lector masculinamente interpelado. Por debajo del binarismo canónico de la cultura impresa, Mansilla permite leer la mezcla entre destino nacional y pasión personal, entre las dimensiones interpersonales del pasado común asignadas al romance y la apertura a lo maravilloso y poco común que brindaba la novela. En su doblez indisciplinado y su exceso desviante, la novela-romance ensayada por Mansilla (que usa ambos términos sin distinción) anticipa el nudo que, en la propuesta de Sommer, vincula las ficciones fundacionales latinoamericanas con las novelas del boom de la década de 1960. La distinción trazada por Lukács en La novela histórica (1937), entre la novela sentimental de Chateaubriand y el romance histórico de Scott, se deshace en Hispanoamérica, donde "los dos son uno, Walter Scott y Chateaubriand, así le pese a George Lukács": "en América Latina, el romance no distingue entre la ética política y la pasión erótica, entre el nacionalismo épico y la sensibilidad íntima, sino que echa por tierra toda distinción" (Sommer, 2004, pp.41-42). ${ }^{13}$

También aquí con un desplazamiento periférico respecto de Europa, los extremos se tocan, los opuestos dejan de serlo. El vértigo capitalista conforma el mundo social masculino pero, como experimenta Mansilla en Una tía reformulando la trama de Machali, la mujer permite exhibir los bordes peligrosos del capitalismo en el nivel político-doméstico de la familia. Como el continuo estamental entre lo público y lo privado, como el gesto teórico que lleva del interior al afuera del texto, como el sedentarismo de guarnición militar que atraviesa las fronteras asignadas, como el prosista novelesco sin novela, como el individuo autosuficiente ligado a asociaciones periodísticas, literarias y políticas, los extremos se entreveran y Mansilla multiplica la máxima suscitada ante las ceremonias oratorias de los ranqueles: "La civilización y la barbarie se dan la mano; la humanidad se

\footnotetext{
${ }^{13}$ Sommer anota que el entrenamiento de Cooper antes de escribir sus grandes romances consistió en imitar "no al varonil autor de romances históricos Walter Scott, sino a esa dama y maestra inglesa de la novela psicológica doméstica, la señorita Jane Austen". Hasta 1823 Cooper "siguió haciéndose pasar por una mujer con el seudónimo de Jane Morgan" (2004, p.76). El emplazamiento de la mujer en roles subalternos no implicaba, para los varones letrados y educadores, dejar de aprovechar esos encantos que a la vez consideraban peligrosos.
} 
salvará porque los extremos se tocan" (Mansilla, 1947, p.115). Como el Fin enlazado al Comienzo hacia el final del monólogo digresivo de la mujer casada en la novelita de César Aira, que frente a una estatua tiene esa "revelación bárbara", el Concluirá del folletinista fronterizo siempre puede hacerse Continuará, la quietud, movimiento, y la civilización, barbarie. Los extremos se enroscan sobre sí mismos en un nudo donde lo diverso aparece junto: las estatuas para la protagonista de Aira, o la escritura para Mansilla y para Aira, son "una especie de máquina de transmutar opuestos" (Aira, 2010, p.76). Al atender al proceso histórico en la evolución de la novela, conectado al deseo privado, a la excitación de la fantasía que moviliza a lectores novelescos no solo femeninos, Mansilla anticipa problemas y posibilidades de la novela latinoamericana que, en el siglo XX, materializará con particular afán el entrevero de intimidad y política. "Típico de mí", podría decir Mansilla como la narradora de Aira en 2010, "que los opuestos se me aparecieran juntos".

\section{Chacota y hechizo}

Como muestran las distintas filiaciones con Cooper, la fuerza retórica de Mansilla tan cercana a Sarmiento trasunta tensiones políticas y personales entre ambos publicistas colocados en desparejos roles oficiales, que se intensificarán durante la presidencia de Sarmiento, cuando Mansilla (luego de apoyar su candidatura y no obtener un ministerio) se corta solo hacia los ranqueles. El distanciamiento del código militar por la constante colaboración en la prensa provocará razonable incomodidad entre figuras destacadas del gobierno nacional: "Como el mismo Sarmiento se encargará de afirmar, ningún otro comandante de frontera contó con una campaña periodística que registrara hasta las más mínimas acciones en el diario más popular de Buenos Aires" (Iglesia, 2003, pp.552). Los disgustos de miembros respetados de la corporación por esa escritura desviada del enclave militar pero allí producida se agravan cuando Mansilla intensifica su escritura de prensa durante la Guerra del Paraguay. En carta privada (a su esposa) el general Juan Andrés Gelly y Obes se queja de "la manía de escribir para la prensa" y la indocilidad de Mansilla, y atinadamente considera peligroso su estilo chacotero: 
Dan náuseas ver y leer las cosas que se escriben sobre el teatro de la guerra como se titulan estas cosas y entre ellas, en primera línea las que escribe Mansilla a quien yo he dicho por varias veces y en presencia de varios que es un traidor y que si fuese general en jefe, no escribía o dejaba de mandar cuerpo en el ejército. Todo lo echa a la chacota y a la broma, siguiendo cada vez más insensato en su modo de apreciar los sucesos y nuestras cosas (Popolizio, 1985, p.134).

Como registra Iglesia en el vademécum que porta su capital literario acumulado en Ranqueles, la escritura en Mansilla sería una actividad "permanente que ilusoriamente tiende a duplicar la vida" (2003, p.547). Percibiendo la fuerza de ese vaivén aunque la anote como defecto, bajo el título elegante de "Los fragmentarios" Rojas agrupó a los escritores que, desde el parámetro filológico nacionalista, consideró "fracasados", "promesas incumplidas": "los que no se adecuan al modelo de 'gran escritor' - esto es, con obra completa y, sobre todo, clasificable- que el crítico tiene en mente" (2003, p.542). La prosa indisciplinada de Mansilla seguirá limitando su valoración literaria después de Rojas; todavía a fines del siglo XX, editores y críticos depuran y aligeran la obra o la acusan de falta de unidad y plan (p.548). ${ }^{14}$ Desacatado, dilatorio y excesivo, dinámicamente fragmentario pero torpemente fragmentado por la institucionalización literaria hasta el siglo XXI, Mansilla se desfasa y se hace inactual, contemporáneo. La temeraria distancia autoconsciente del romanticismo fundacional, la fuerza de transición hacia un realismo no naturalista y una novela de imaginación y pensamiento pero no de tesis, son visibles en su propia obra; pero además, por efecto retrospectivo emanado de textualidades ficcionales y críticas que en el cambio de milenio lo hacen precursor, no solo adelanta una posición de autor como escritor y genera posibilidades novelísticas enfocadas en el doblez entre imaginario y real, también formula un cuestionamiento anacrónico a la especificidad literaria frente a la proliferación de discursos y medios referidos a la realidad: a la vez que

\footnotetext{
${ }^{14}$ Iglesia $(2003$, pp.542, 548) detecta la reiteración de la descalificación de Rojas en la Historia de la literatura argentina editada por CEAL en 1967-68, en cuya edición de 1980-86 no se consideró necesaria la inclusión de nuevos enfoques críticos para el caso de Mansilla. Además de recortes en ediciones de Ranqueles con pretexto de no quitar unidad y fuerza a la obra, Iglesia anota la sorprendente advertencia preliminar en la edición de Entre-nos de El Elefante Blanco en 2000: "el manuscrito era muy largo y hemos dejado caer algunas hojas".
} 
problematiza la posibilidad de que la literatura sea "una modalidad específica de referirse a la realidad", como en la abundante producción literaria del presente, el desplazado Mansilla sigue “actuando, si no lidiando, para mantener una posición peculiar en los discursos simbólicos que circulan en una sociedad" (Premat, 2017, pp.315-316). La máquina de transmutar opuestos afecta las coordenadas espaciales y temporales, y sigue funcionando acaso más plenamente en el siglo XXI.

Inquieto en el ordenancismo castrense desde el cual desplegó menos triunfos militares que experimentos textuales, Mansilla convirtió su vida en escritura y él mismo fue el primer objeto que tomó a broma (sin por eso dejar de tomarse en serio, porque los extremos se tocan). Las condiciones de legibilidad de nuestro presente propician el disfrute de aquello temido por los jefes militares de este insubordinado chacotero que pretendía dominar la impaciencia de los otros, cuyos textos inactuales, cada vez más insensatos, problematizan los modos contemporáneos de apreciar los sucesos y nuestras cosas. El Ensayo sobre la novela en la Democracia termina conectando ese abierto estatuto genérico - ensayo- con la expansión de la imaginación y el desorden bien acompañados por el lector: "No fue por cierto mi intención remontarme hasta donde el lector me ha seguido. Pero quién puede decirle a su imaginación de aquí no pasarás [...]. Ahí tenéis por qué léese la palabra Ensayo en el epígrafe" (2013, p.151). Cruzando lo novelístico y ensayístico en la duplicación ilusoria de la vida, la escritura de Mansilla acomete el desafío que postuló para la literatura democrática al final de la primera entrega del ensayo escrito desde Rojas en 1863: encontrar "en los episodios de vida real suficiente hechizo" (Mansilla, 2013, p.128) para atrapar al lector, dilatarlo del vértigo social en un tejido de aventuras tan sentimentales como materiales, emanadas de la sociedad de individuos prácticos. En la fuga del repetido continuará, el ensayo novelístico de Mansilla sigue contestando a una solicitación que le viene del futuro. La incipiente sistematización de Literatura/Sociedad en fragmentos de prosa novelesca sin novela, reunidos por la unidad vital de un sujeto múltiple (des)figurado en la escritura, se desfasan de su tiempo como ligeras promesas pendientes, en un jocoso y dilatado concluirá. 


\section{Referencias:}

Aira, C. (2010). Yo era una mujer casada. Buenos Aires: Blatt \& Ríos.

Alberdi, J. B. (s/f). Certamen poético. Páginas literarias, Tomo I. Buenos Aires: La Facultad.

Altamirano, C. y Sarlo, B. (1993). Literatura/Sociedad. Buenos Aires: Edicial.

Bruno, P. (2009). La vida letrada porteña entre 1860 y el fin-de-siglo. Coordenadas para un mapa de la elite intelectual. Anuario IEHS, número 24, 339-368.

Cortázar, J. (1994). Historias de Cronopios y de Famas. Buenos Aires: Sudamericana.

Degiovanni, F. (2007). Los textos de la patria: nacionalismo, políticas culturales y canon en Argentina. Rosario: Beatriz Viterbo.

Iglesia, C. (2003). Mansilla, la aventura del relato. Schvartzman, Julio (dir. del vol.). La lucha de los lenguajes, vol. 2 de Jitrik, Noé (dir.). Historia crítica de la literatura argentina. Buenos Aires: Emecé, pp.541-563.

Mansilla, L. V. (2013). Ensayo sobre la novela en la Democracia o Juicio crítico sobre la Emilia de R. el Mujiense. Edición crítica a cargo de Pablo Colombi y Natalia Crespo. En Revista de Literaturas Modernas, 43 (2), 117-151.

Mansilla, L. V. (1947). Una excursión a los indios ranqueles. México: FCE.

Molina, H. (2011). Como crecen los hongos: la novela argentina entre 1838 y 1872. Buenos Aires: Teseo.

Myers, J. (1998). La revolución de las ideas: la generación romántica de 1837 en la cultura y en la política argentinas. Goldman, Noemí (dir.), Polotto, Federico (ed.), Suriano, Juan (coord.). Nueva historia argentina. Tomo III: Revolución, República, Confederación (1806-1852). Buenos Aires: Sudamericana, pp.383-443.

Popolizio, E. (1985). Vida de Lucio V. Mansilla. Buenos Aires: Pomaire.

Premat, J. (2017). La literatura hoy: de nuevo lo nuevo. Notas sobre Una belleza vulgar de Damián Tabarovsky. Mil hojas. Formas contemporáneas de la literatura (Carlos Walker comp.). Santiago de Chile: Hueders, pp.315-342. 
Premat, J. (2018). Non nova sed nove. Inactualidades, anacronismos, resistencias en la literatura contemporánea. Macerata: Quodlibet.

Rodríguez Pérsico, A. (2017). Juan Bautista Alberdi: nación y razón. En: Los unos y los otros. Comunidad y alteridad en la literatura latinoamericana. Villa María: Eduvim, pp.23-52.

Rojas, R. (1957). Historia de la literatura argentina. Ensayo filosófico sobre la evolución de la cultura en el Plata. Los modernos. Buenos Aires: Guillermo Kraft.

Roldán, D. (2005). Sarmiento, Tocqueville, los viajes y la democracia en América. Revista de Occidente, número 289, Madrid, junio, 35-60.

Sarmiento, D. F. (1961). Facundo. Prólogo y notas de Alberto Palcos. Buenos Aires: Ediciones Culturales Argentinas.

Schvartzman, J. (2013). Letras gauchas. Buenos Aires: Eterna Cadencia.

Sommer, D. (2004). Ficciones fundacionales: las novelas nacionales de América Latina. Traducción José Leandro Urbina y Ángela Pérez. Bogotá: FCE.

Terán, O. (2000). Vida intelectual en el Buenos Aires fin-de-siglo (1880-1910). Derivas de la "cultura científica". Buenos Aires: FCE.

Viñas, D. (1999-2004). Mansilla entre Rozas y París. Biblioteca Nacional Mariano Moreno (Argentina), Departamento de Archivos, Fondo David Viñas (AR-BNMM-ARCH-DV).

Zanetti, S. (2002). La dorada garra de la lectura. Lectoras y lectores de novela en América Latina. Rosario: Beatriz Viterbo. 


\section{ANEXO: ESPACIO IMPRESO}

Todas las imágenes fueron tomadas de repositorios de la Biblioteca Nacional de Argentina. Material de dominio público, publicaciones libres de derechos de autor.

Primera entrega del Ensayo, 23 y 24 de noviembre de 1863, número 2967.

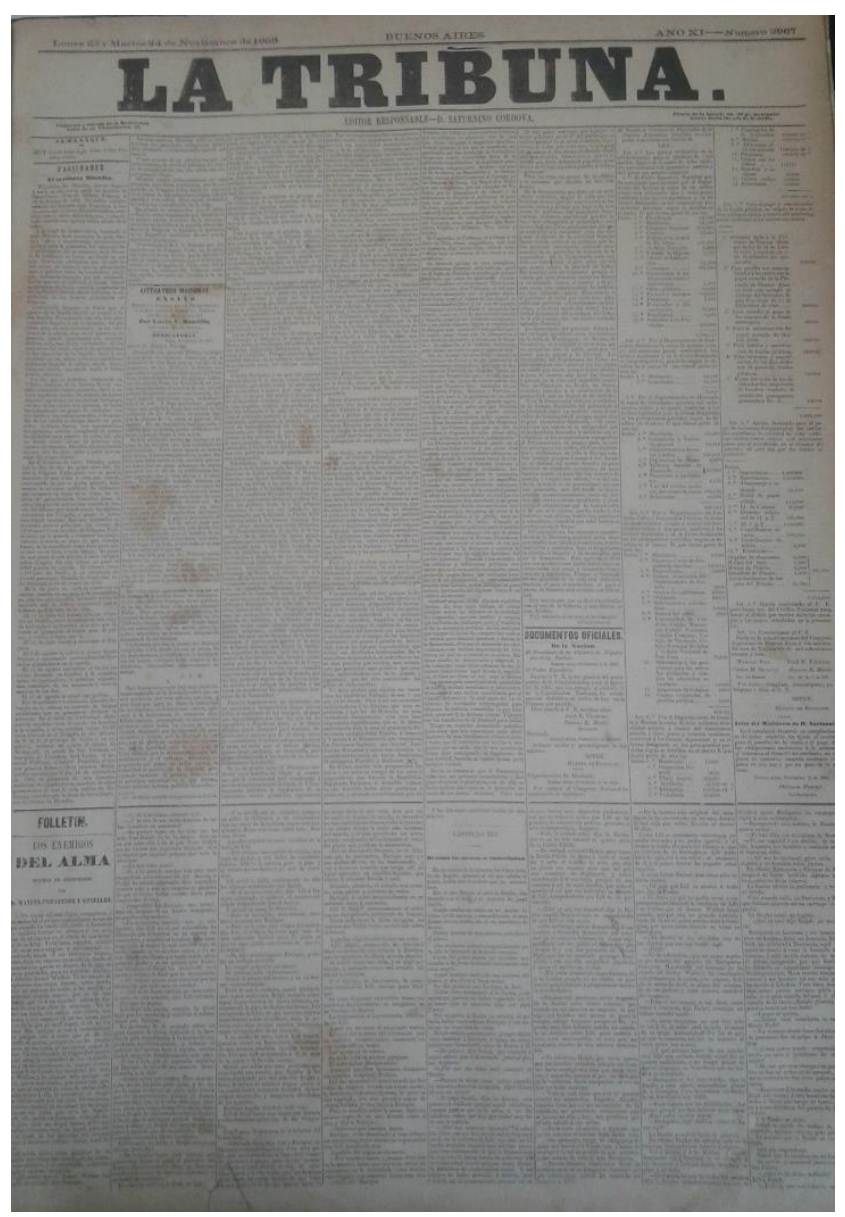

Fotografía Juan Pablo Luppi 
Detalle del Ensayo, primera entrega

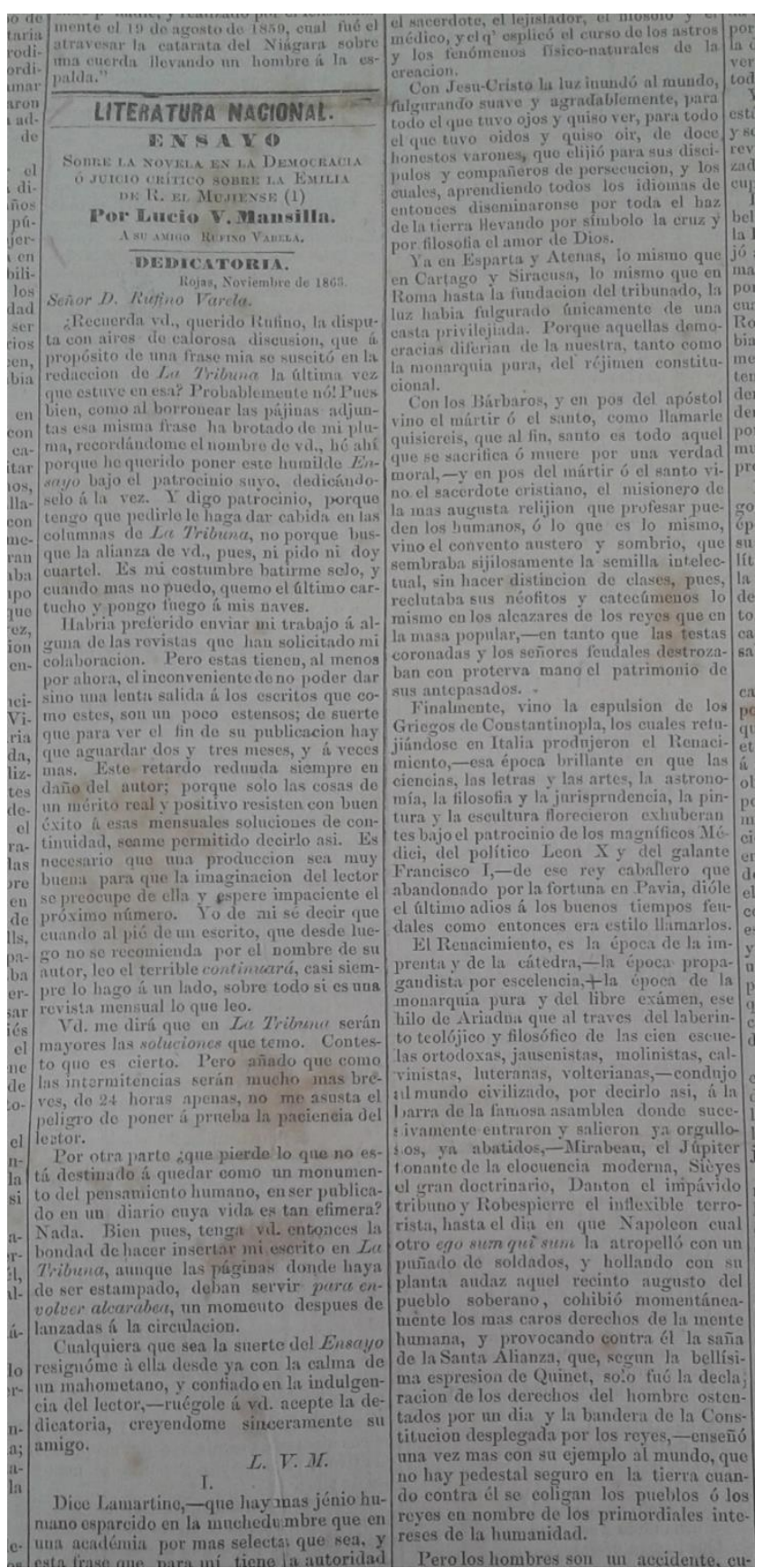

Fotografía Juan Pablo Luppi 
Segunda entrega: 25 de noviembre, número 2968.

Primera plana, semi tapada por hoja suelta enganchada, que porta noticia festiva sobre asesinato estatal del caudillo Ángel Vicente Peñaloza: “Derrota y muerte del Chacho: ¡Hurrah!”
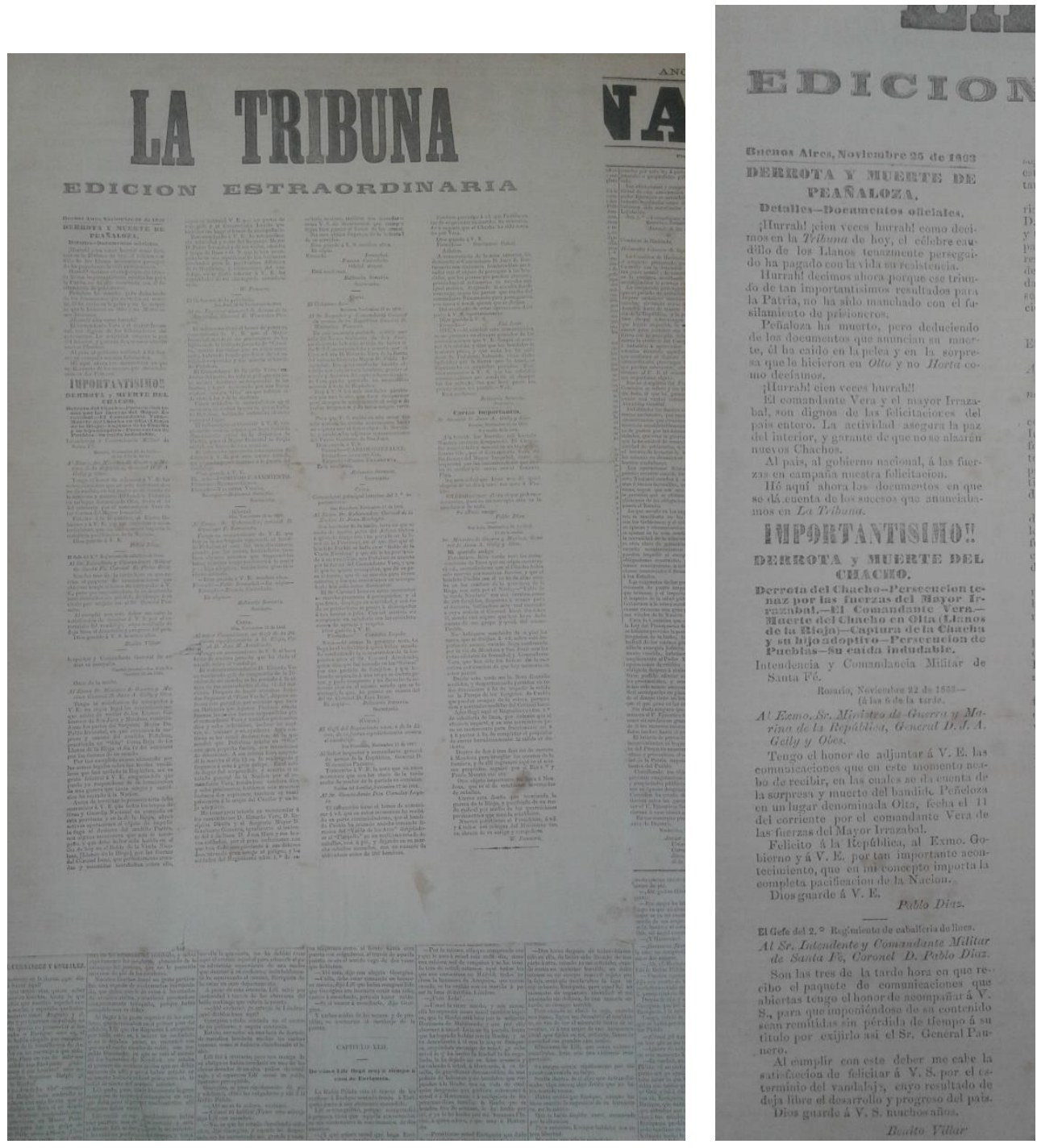

Fotografía Juan Pablo Luppi 


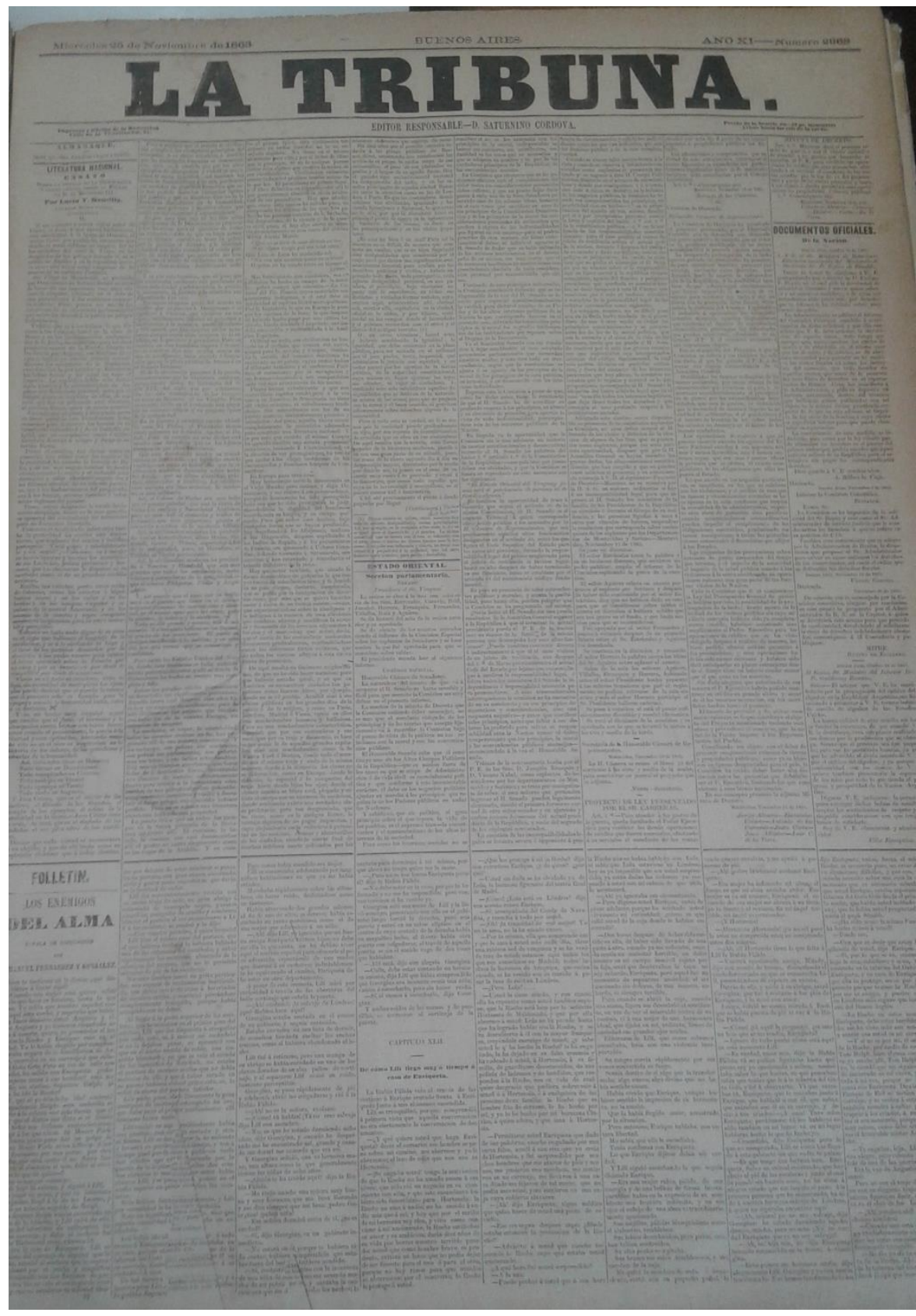

Fotografía Juan Pablo Luppi 
Tercera entrega: 27 de noviembre, número 2970.

Escondido en la sexta columna, hacia arriba.

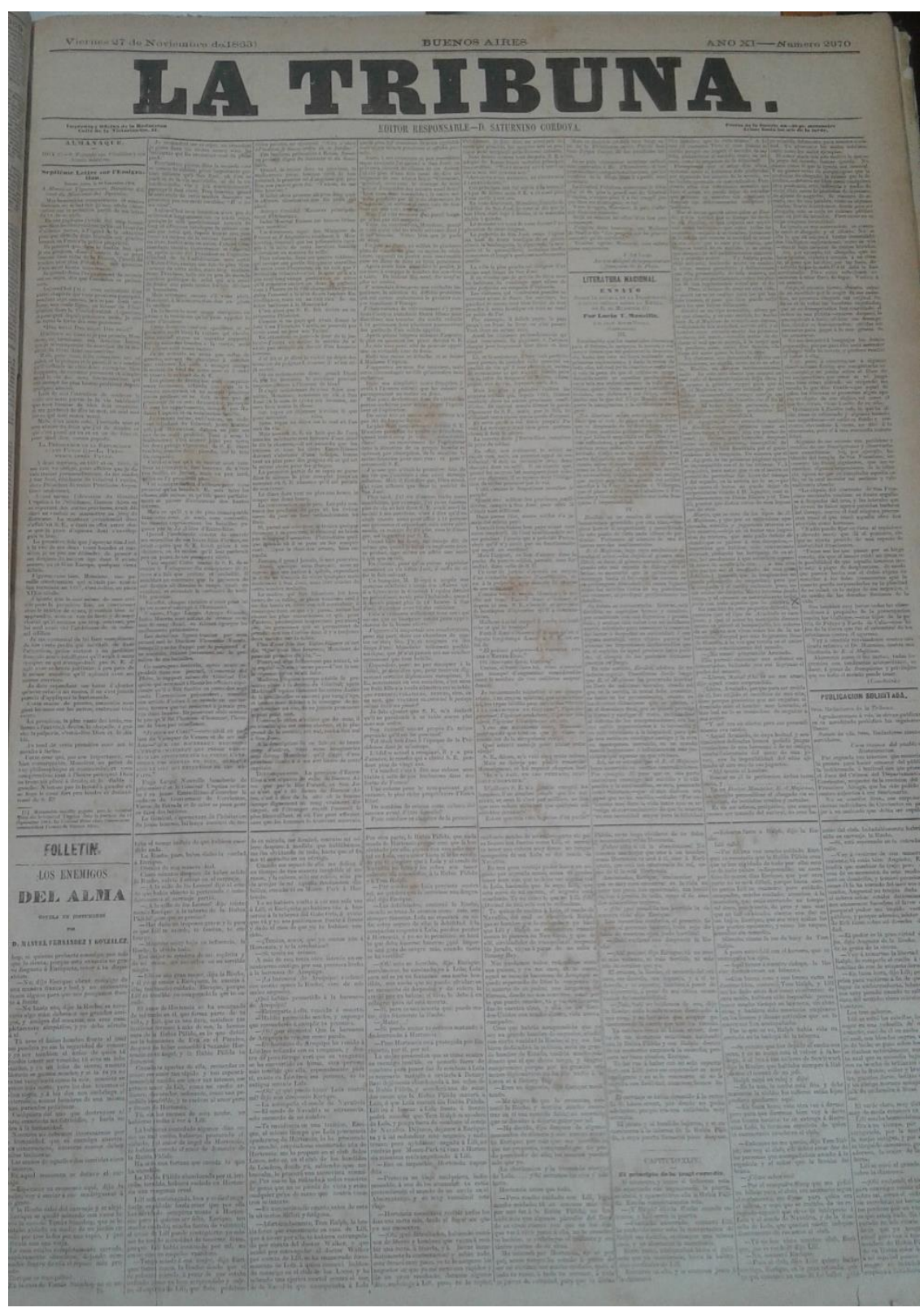

Fotografía Juan Pablo Luppi 
Cuarta y última entrega: 28 de noviembre, número 2971.

Vuelve al sitio destacado, arriba a la izquierda, primer texto de tapa.

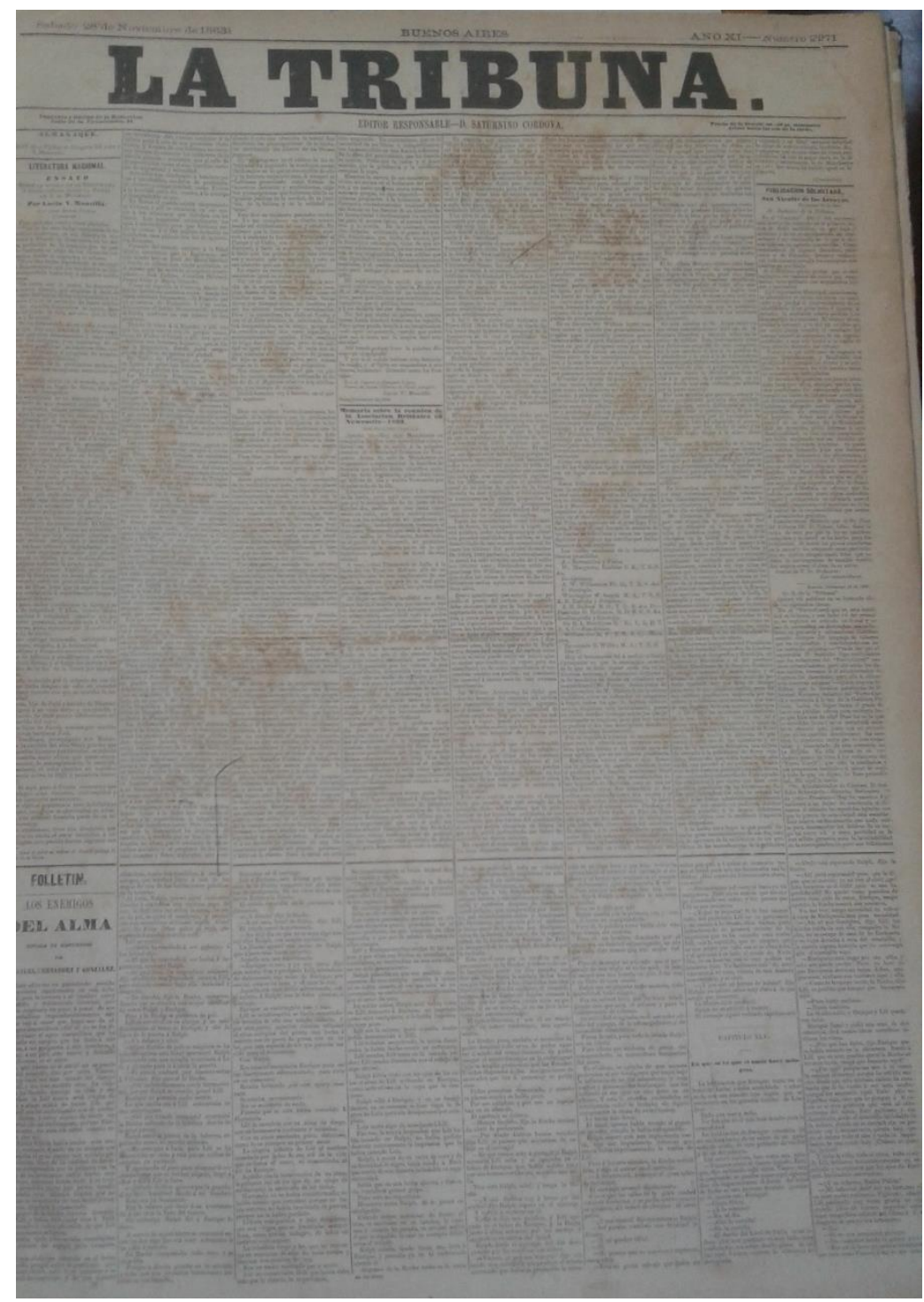

Fotografía Juan Pablo Luppi 


\section{Última página del diario, irrumpida por mercado.}

Arte gráfico publicitario, en los comienzos de una democracia capitalista periférica

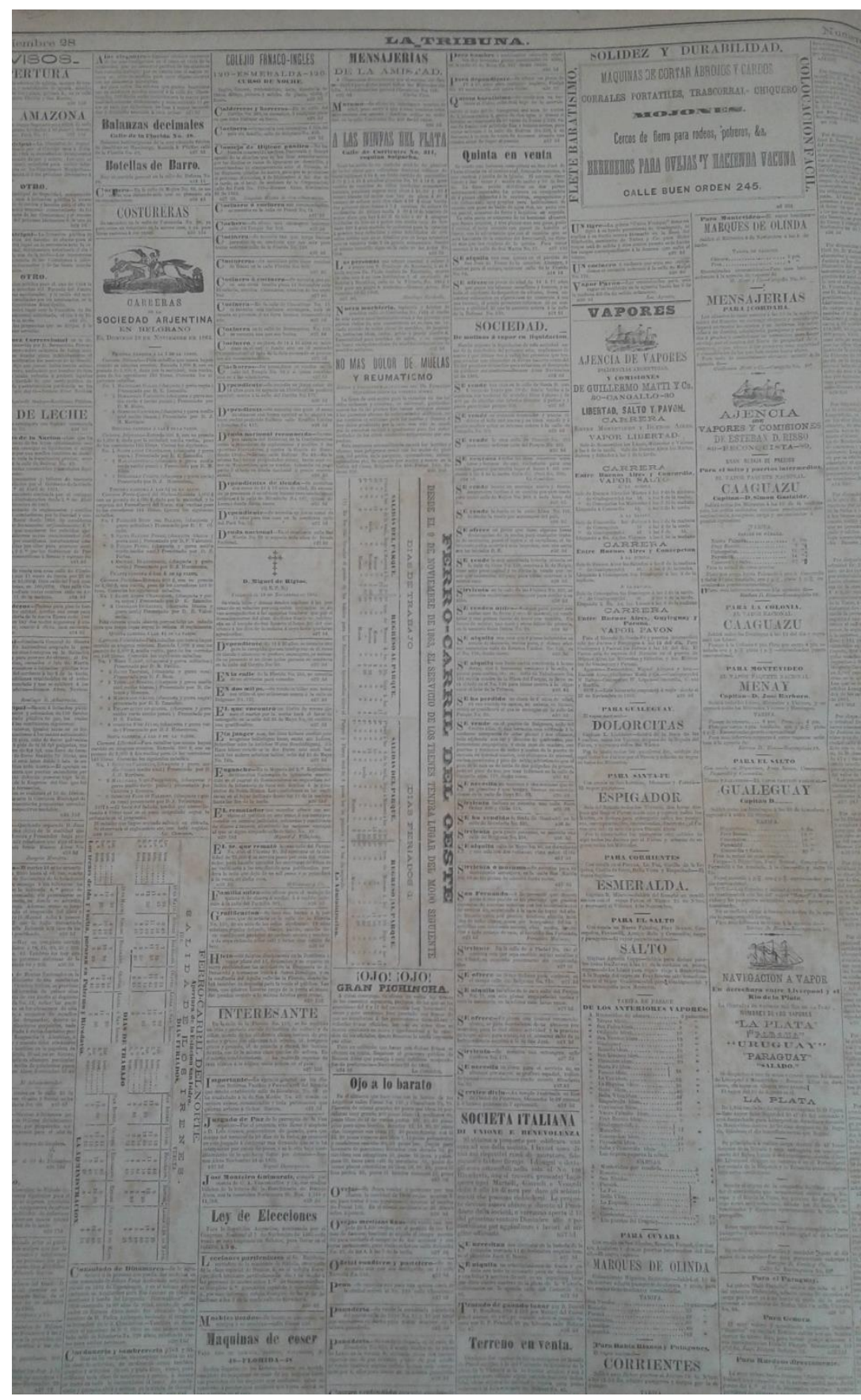

Fotografía Juan Pablo Luppi 
La novela-excusa, o la educación moral de las mujeres.

Folletín en libro ilustrado (Imprenta de la Bolsa, 1862)

\section{Ex)XXXa}

b

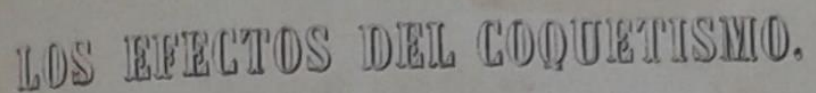

POR

R. EL MUGIENSE.

Fotografía Juan Pablo Luppi 


\section{EVILIA}

ó

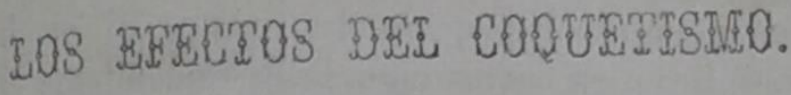

unoroma

\section{INTRODUCCION.}

\section{La Falsia.}

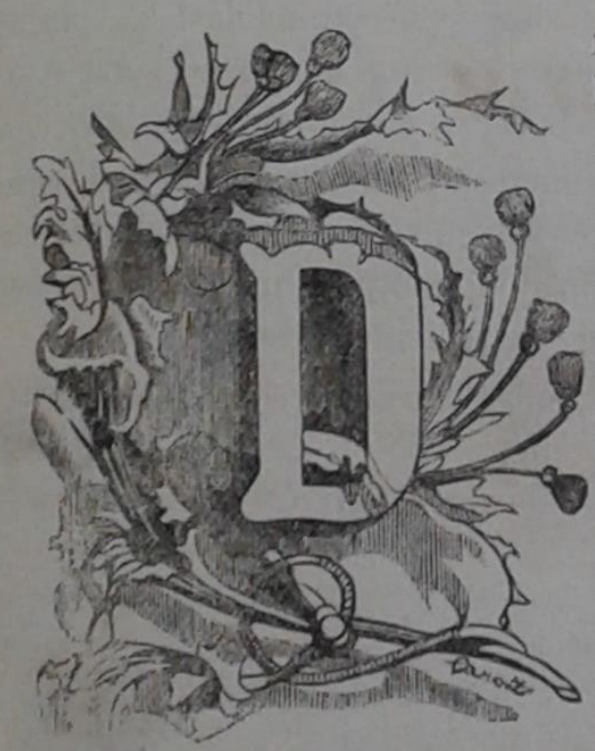

ISTINGUESE con el nombre de coqueta, la mujer inclinada á ocultar las tendencias de su corazon por medio de palabras y gestos, haciendo un estudio particular de todos sus actos exteriores, por manera que la coqueta es una mezcla original de infierno y gloria, de demonio y ángel que nadie puede definir con exactitud.

La imajinacion empero, debe suplantar la carencia de lintes indispensables para fotografiar ese ser voluble é inconstante que comienza á abundar entre nosotros.

Fotografía Juan Pablo Luppi 
Sr. D. Ramon Borras.

\section{Estimado amigo mio:}

Le prometí unos articulos bosquejando algunos tipos de este pais

Escritos los primeros articulos, varié de pensamiento ligándolos entre si, para formar algo.

No sê si lo he conseguido, pero tal cuales son, se los dedica como una prueba de sincera amistad.

Sr. $D$.

\section{Estimado amigo:}

He leido con el mayor placer los articulos que sesirve dedicarme, y sin querer entrar á juzgar de su mérito, para lo que me declaro incompetente, puedo asegurarle que me han agradado, y tal cuales son, no estrañe verlos publica. dos algun dia.

Agosto 10 de 1862.

$$
\text { R. el Mujiense. }
$$

\section{IIIDICB.}

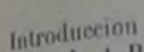

y Placeres

2 Reconvencion oportuma

Hastio y celos

4 Dificnltad vencida.

5 Consuclo y esperanza.

6 Tardio arrepentimicnt

7 HI Rompimiento

8 EI Ilogar Pateruo.

9 Delia

10 FI Dr, Yanzano.

II En la Quinta.

12 Al fin....jGallego:

13 In mal dia.

if Los dos hermano

15 Escena Oscura,

16 La Esquina de Perez.

17 Lealtád ejemplar.

18 Ja Partida.

19 Revelaciones

20 Ina Invasion

21 Felicidal

22 Presentimis ato-

23 sorprea y llapto.

24 El io de Noviembre.

25 Efectos del Coquetiano Kprlogo.

Rumon Bornís.

Fotografía Juan Pablo Luppi 